\title{
SARS-CoV-2 antibody persistence after five and twelve months: A cohort study from South-Eastern Norway
}

Marjut Sarjomaa ${ }^{1,2^{*}}$, Lien My Diep ${ }^{3}$, Chi Zhang ${ }^{3,4}$, Yngvar Tveten ${ }^{5}$, Harald Reiso ${ }^{6}$, Carina Thilesen ${ }^{7}$, Svein Arne Nordb $\emptyset^{8,9}$, Kristine Karlsrud Berg ${ }^{10}$, Ingeborg Aaberge ${ }^{4}$, Neil Pearce ${ }^{11}$, Hege Kersten ${ }^{12,13}$, Jan Paul Vandenbroucke ${ }^{11,14,15}$, Randi Eikeland ${ }^{16,17}$, Anne Kristin Møller Fell 2,17

1 Department of Infection Control, Telemark Hospital Trust, Skien Norway, 2 Department of Community Medicine and Global Health and Society, University of Oslo, Norway, 3 Oslo Centre for Biostatistics and Epidemiology, Oslo, Norway, 4 Norwegian Institute of Public Health, Oslo, Norway, 5 Department of Clinical Microbiology, Telemark Hospital Trust, Skien, Norway, 6 The Norwegian National Advisory Unit on Tick-borne Diseases, Sørlandet Hospital Trust, Arendal, 7 Unilabs Laboratory Medicine, Skien, Norway, 8 Department of Medical Microbiology, St. Olavs Hospital, Trondheim University Hospital, Trondheim, Norway, 9 Norwegian University of Science and Technology, Trondheim, Norway 10 Department of Medical Microbiology, Sørlandet Hospital Trust, Kristiansand, Norway, $\mathbf{1 1}$ London School of Hygiene and Tropical Medicine, London, United Kingdom, 12 Department of Research, Telemark Hospital Trust, Norway, 13 School of Pharmacy, University of Oslo, Norway, 14 University of Leiden, Leiden, Netherlands, 15 University of Aarhus, Aarhus, Denmark, 16 Department of Health and Nursing Science, University of Agder, Grimstad, Norway, 17 Department of Occupational and Environmental Medicine, Telemark Hospital Trust, Skien, Norway

* Corresponding author:

Email: sarm@sthf.no (MS) 


\section{Abstract}

\section{Objectives:}

To assess total antibody levels against Severe Acute Respiratory Syndrome CoronaVirus 2 (SARS CoV2) spike protein up to 12 months after Coronavirus Disease (COVID-19) infection in non-vaccinated individuals and the possible predictors of antibody persistence.

\section{Methods:}

This is a prospective multi-centre longitudinal cohort study.

\section{Participants}

The study included SARS-CoV-2 real-time polymerase chain reaction (RT-PCR) positive and negative participants in South-Eastern Norway from February to December 2020. Possible predictors of SARSCoV-2 total antibody persistence was assessed. The SARS-CoV-2 total antibody levels against spike protein were measured three to five months after PCR in 391 PCR-positive and 703 PCR-negative participants; 212 PCR-positive participants were included in follow-up measurements at 10 to 12 months. The participants completed a questionnaire including information about symptoms, comorbidities, allergies, body mass index (BMI), and hospitalisation.

\section{Primary outcome}

The SARS-CoV-2 total antibody levels against spike protein three to five and 10 to 12 months after PCR positive tests.

\section{Results:}

SARS-CoV-2 total antibodies against spike protein were present in 366 (94\%) non-vaccinated PCRpositive participants after three to five months, compared with nine (1\%) PCR-negative participants. After 10 to 12 months, antibodies were present in 204 (96\%) non-vaccinated PCR-positive participants. Of the PCR-positive participants, 369 (94\%) were not hospitalised. The mean age of the PCR-positive participants was 48 years (SD 15, range 20-85) and $50 \%$ of them were male. $\mathrm{BMI} \geq 25$ $\mathrm{kg} / \mathrm{m}^{2}$ was positively associated with decreased antibody levels (OR $2.34,95 \% \mathrm{Cl} 1.06$ to 5.42 ). Participants with higher age and self-reported initial fever with chills or sweating were less likely to have decreased antibody levels (age: $\mathrm{OR} 0.97,95 \% \mathrm{Cl} 0.94$ to 0.99 ; fever: $\mathrm{OR} 0.33,95 \% \mathrm{Cl} 0.13$ to 0.75).

\section{Conclusion}

Our results indicate that the level of SARS-CoV-2 total antibodies against spike protein persists for the vast majority of non-vaccinated PCR-positive persons at least 10 to 12 months after mild COVID19.

Key words: Covid-19, SARS-CoV-2, humoral immune response, antibodies 


\section{Introduction}

Since the initial outbreak of COVID-19 was reported in Wuhan in December 2019, over 304 million people have been infected worldwide, with over 5.4 million deaths reported by the World Health Organization (WHO) as of 11th January 2022 [1]. The first wave of the pandemic in Norway peaked in March 2020. The second wave started in the autumn of 2020 and the third wave in February 2021. The estimated seroprevalence of SARS CoV- 2 antibodies in Norway was $0.6 \%$ in the late summer of 2020 and increased to $3.2 \%$ in January 2021, after the second wave [2].

The impact of SARS-CoV-2 on human health in individuals and populations depends on multiple factors such as the level of healthcare, diagnostics, therapeutics, social distancing measures such as lockdowns, face masks, working from home, and the availability and coverage of vaccines to control the disease. Understanding the cellular and humoral immunity to COVID-19 is necessary to assess the future course of the pandemic. There is still insufficient data regarding the long-term persistence of antibodies and the level of protective immunity, especially in patients who underwent mild infections and those who were not hospitalised [3-9]. Hence, there is a need for studies on antibody kinetics to improve our understanding of humoral immunity following COVID-19 infections.

The gold standard for antibody test assays has not been determined, and numerous immunoassays have been developed [10]. IgG antibodies against SARS-CoV-2 are highly sensitive markers 7-14 days after symptom onset $[8,11]$. Antibodies are detected in $90 \%$ of individuals after two weeks and are highly correlated with neutralising antibodies $[8,12]$. High sensitivity and specificity are important for all serological assays, and the specificity of an antibody test might be an issue when the infection prevalence is low [13]. Some smaller studies early in the pandemic showed that antibodies declined within a few months after infection [14-16]. Antibody levels against the nucleocapsid protein have been shown to decline more rapidly than antibodies against the spike protein [12]. Furthermore, the kinetics and protective immunity between anti-nucleocapsid and anti-spike antibodies may differ [17]. Data from large, systematic, and quantitative follow-up studies of antibodies for longer than six to eight months are limited $[18,19]$.

The study of antibody persistence is still important, despite vaccination, as antibody longevity during an ongoing pandemic is of scientific interest, as well as being particularly relevant for providing correct and informed vaccination strategies to those who have had an infection. However, there is still a lack of knowledge regarding the longevity of protective immunity.

Our aim was to assess the SARS-CoV-2 total antibody levels against spike protein up to 12 months after COVID-19 infection in non-vaccinated individuals, and identify possible predictors for antibody persistence [20].

\section{Materials and methods}

\section{Study design and setting}

Adults aged 18 years or older residing in South-Eastern Norway (Agder and Telemark counties) were considered eligible for inclusion in the study. Participants were recruited from all hospitals in the region, municipality laboratories, and test centres between February 28 and December 17, 2020. For each PCR-positive (PCR+) participant, we selected two PCR- negative (PCR-) participants matched by residency and time for the PCR test. The main reason for including PCR- negative participants was the possibility for further studies assessing risk factors, reinfections and vaccine responses. 
medRxiv preprint doi: https://doi.org/10.1101/2022.02.16.22271075; this version posted February 21, 2022. The copyright holder for this preprint (which was not certified by peer review) is the author/funder, who has granted medRxiv a license to display the preprint in perpetuity.

It is made available under a CC-BY 4.0 International license.

Participants who did not consent or were unable to answer a questionnaire (Norwegian language) were excluded. COVID-19 vaccination was introduced in January 2021, and post-vaccine samples were excluded in this study.

The official Norwegian testing criteria for SARS-CoV-2 changed over time but were the same for the matched PCR+ and PCR- participants. In the first wave of the pandemic, PCR testing was restricted to patients with symptoms. In the second wave, PCR testing was also applied to close contacts and asymptomatic persons during outbreaks. All participants were invited to the sampling of antibodies and were asked to fill in the self-reporting questionnaire simultaneously, three to five months (time point $1=T 1$ ) after the $P C R$ test. The group of non-vaccinated $P C R+$ participants were invited for follow-up 10 to 12 months (time point $2=T 2$ ) after the PCR test.

Participation was voluntary, and participants were not offered any financial incentives.

\section{Data sources/measurement}

\section{Questionnaire}

Questions from the Norwegian Health Institute COVID-19 questionnaire and the validated Telemarkstudy questionnaire were used [21-24], in addition to questions provided by the study group. A user representative was involved in the process of piloting the questionnaire. Questions are shown in S1 Table.

The questionnaire consisted of questions about demographic data, income, education, smoking habits, hospitalisation, and comorbidities such as asthma and chronic obstructive pulmonary disease (COPD), other lung diseases, cancer, heart disease, diabetes, hypertension, musculoskeletal disease, any other disease and pollen allergy. Questions about symptoms included the presence or absence of cough, runny nose, stuffy nose, sore throat,dyspnoe, headache, fever with chills or sweating, abdominal pain, nausea, diarrhoea, impaired sense of smell and taste, myalgia, and dizziness. Questions regarding fatigue and reinfection were also included.

Self-reported vaccination data were available and checked against data from the National Immunisation Register (SYSVAK). Additional demographic data (age, sex, and time and place for SARS-CoV-2 PCR) were also registered.

\section{Laboratory methods}

Venous blood samples were obtained at recruitment, three to five months after the PCR test (T1), and again after 10-12 months (T2). All serum samples were prepared from whole blood following centrifugation for $10 \mathrm{~min}$ at a minimum of $1800 \mathrm{~g}$ at room temperature and stored at $-80^{\circ} \mathrm{C}$ until further analysis. Total immunoglobulin levels were analysed at Telemark Hospital using the Siemens Advia Centaur XP SARS-CoV-2 Total assay for the qualitative detection of total antibodies (IgM and $\lg \mathrm{G}$ ) in human serum. On a large panel of blood samples, the Siemens assay achieved a sensitivity and specificity of at least $98 \%$ [10]. The assay is a fully automated 1-step antigen sandwich immunoassay using acridinium ester chemiluminescent technology and recombinant SARS-CoV-2 S 1 receptor binding domain (RBD) antigen. The total antibody ranged from 0 to 9.99 , and $\geq 10$ was the upper limit of the assay. The threshold for reactivity was $\geq 1.0$ Index. To make it possible to interpret changes in antibody levels, antibody levels were categorised into four categories: negative (0-0.79), low (0.80-1.99), intermediate (2.00-9.99), and high ( $\geq 10)$.

To reduce the possibility of false positive results, low antibody levels between 0.80 and 1.99 Index value were reanalyzed at St. Olavs Hospital in Trondheim using the Elecsys Cobas SARS-CoV- 2 total antibody test (Roche) and BioPlex 2200 SARS-CoV-2 IgG Panel (Bio-Rad). 
medRxiv preprint doi: https://doi.org/10.1101/2022.02.16.22271075; this version posted February 21, 2022. The copyright holder for this preprint (which was not certified by peer review) is the author/funder, who has granted medRxiv a license to display the preprint in perpetuity.

It is made available under a CC-BY 4.0 International license .

\section{Ethics approval and consent to participate}

All participants provided written informed consent before inclusion. The Study was approved by the Regional Committee for Medical and Health Research Ethics of South East Norway A (ID 146469), the Norwegian Centre for Research Data (NSD), and the Data Protection Officers in the participating hospitals.

\section{Statistical analysis}

Mean, standard deviation (SD), medians, interquartile ranges (IQR), and minimum and maximum values were reported for continuous data as appropriate. Categorical data were reported as frequencies and percentages.

The difference between the observed antibody values at $\mathrm{T} 1$ and $\mathrm{T} 2$ were calculated. The changes that were greater than the maximum level of 10 Index could not be quantified due to the limitations of the assay. Hence, for further analysis, the participants were categorised into four antibody groups: decreased, unchanged, increased, and maximum level $\geq 10$. An increase or decrease of at least $20 \%$ in antibody values from T1 to T2 was defined as a significant change; otherwise, the participant was assigned to the unchanged antibody group. Chi-squared and Fisher's exact tests were used to examine differences in proportions between the decreased antibody group and the other groups (unchanged, increased, and maximum antibody level $\geq 10$ ) for binary variables. For continuous and ordinal variables, the Kruskal-Wallis test and the One-Way Anova was used to study the difference. Total symptom and comorbidity scores were calculated by adding the number of symptoms or comorbidities for each participant, and used instead of single variables in the multivariate analysis.

Logistic regression models were used to study the possible predictors for changes in antibody levels. Univariate analysis was performed for each predictor, adjusting for age and sex. Then, a multivariate analysis including all predictors was performed, and the standard error of the effect estimate was compared to that of the corresponding univariate analysis for each predictor to check for collinearity. Odds ratio (OR) was reported with 95\% confidence intervals ( $\mathrm{Cl}$ ) for association between decreased antibody level and predictors. The analyses were performed with IBM SPSS 27 for Windows (IBM Corp. Released 2020. IBM SPSS Statistics for Windows version 27.0. Armonk, NY: IBM Corp), Stata/SE 16.1 for Windows and $R$ (version 4.2).

\section{Results}

Between February 28 and December 17, 2020, 656 PCR+ participants and 923 PCR-controls matched in time and location to the PCR+ participants were eligible. In summary, $232 \mathrm{PCR}+$ participants and 92 PCR-participants did not meet the inclusion criteria. Nine PCR+ and 16 PCR-participants were vaccinated prior to the first antibody sampling and were excluded from the study. The number of individuals assessed for eligibility and individuals included in the study is shown in Fig $\mathbf{1 .}$

\section{Fig 1. Flow chart for the study.}

The demographics of the study population by baseline are presented in Table 1.

Table 1. Characteristics of the PCR positive (PCR+) and PCR negative (PCR-) participants at the first antibody test (T1).

\begin{tabular}{|l|c|c|c|}
\hline \multirow{2}{*}{ Characteristics } & Total (N = 1094) & PCR+ (N=391) & PCR- (N= 703) \\
\cline { 2 - 4 } & $\mathbf{N ~ ( \% )}$ & $\mathbf{N}(\%)$ & $\mathbf{N}(\%)$ \\
\hline
\end{tabular}


medRxiv preprint doi: https://doi.org/10.1101/2022.02.16.22271075; this version posted February 21, 2022. The copyright holder for this preprint (which was not certified by peer review) is the author/funder, who has granted medRxiv a license to display the preprint in

perpetuity.
It is made available under a CC-BY 4.0 International license .

\begin{tabular}{|c|c|c|c|}
\hline Age in years, mean (SD) & $47.5(14.6)$ & $47.9(15.0)$ & $47.3(14.3)$ \\
\hline $\mathrm{N}$ (range) & $1094(19-98)$ & $391(20-85)$ & $703(19-98)$ \\
\hline BMI in $\mathbf{k g} / \mathrm{m}^{2}$, median (IQR) & $26.6(23.2-29.1)$ & $26.4(23.2-28.7)$ & $26.8(23.3-29.3)$ \\
\hline $\mathrm{N}$ (range) & $1057(15.7-65.6)$ & $374(16-43)$ & $683(16-66)$ \\
\hline BMI in $\mathrm{kg} / \mathrm{m}^{2} \geq 25$ & $598(56.6)$ & $206(55.1)$ & $392(57.4)$ \\
\hline Gender, males & $435(39.8)$ & $196(50.1)$ & $239(34.0)$ \\
\hline \multicolumn{4}{|l|}{ Income } \\
\hline$<500000$ NOKa $^{a}$ & $216(20.4)$ & $68(17.4)$ & $148(21.1)$ \\
\hline $500000-1000000$ NOK & $474(44.7)$ & $162(41.4)$ & $312(44.4)$ \\
\hline$\geq 1000000$ NOK & $365(34.6)$ & $137(35.0)$ & $228(32.4)$ \\
\hline \multicolumn{4}{|l|}{ Education } \\
\hline Primary \& secondary school & $116(10.6)$ & $40(10.2)$ & $76(10.8)$ \\
\hline High school \& certificate & $362(33.1)$ & $146(37.3)$ & $216(30.7)$ \\
\hline University less than 4 years & $342(31.3)$ & $128(32.7)$ & $214(30.4)$ \\
\hline University $>4$ years & $255(23.3)$ & 66 (16.9) & 189 (26.9) \\
\hline \multicolumn{4}{|l|}{ Smoking } \\
\hline Non-smoker & $527(56.0)$ & $213(61.5)$ & $314(52.8)$ \\
\hline Past smoker & $302(32.1)$ & $103(29.8)$ & $199(33.4)$ \\
\hline Occasional and daily smoker & $112(11.9)$ & $30(8.7)$ & $82(13.8)$ \\
\hline \multicolumn{4}{|l|}{ Comorbidity } \\
\hline Asthma & $195(17.8)$ & $61(15.6)$ & $134(19.1)$ \\
\hline COPD & $34(3.1)$ & $7(1.8)$ & $27(3.8)$ \\
\hline Other chronic lung disease & $44(4.0)$ & $16(4.1)$ & $28(4.0)$ \\
\hline Cancer & $37(3.4)$ & $7(1.8)$ & $30(4.3)$ \\
\hline Heart disease & $48(4.4)$ & $16(4.1)$ & $32(4.6)$ \\
\hline Diabetes & $47(4.3)$ & $20(5.1)$ & $27(3.8)$ \\
\hline Hypertension & $110(10.1)$ & $39(10.0)$ & $71(10.1)$ \\
\hline Musculoskeletal disease & $63(5.8)$ & $17(4.3)$ & $46(6.5)$ \\
\hline Any other disease & $194(17.7)$ & $55(14.1)$ & $139(19.8)$ \\
\hline No disease & $554(50.6)$ & $211(54.0)$ & $343(48.8)$ \\
\hline Pollen allergy & $298(27.2)$ & $96(24.6)$ & $202(28.7)$ \\
\hline \multicolumn{4}{|l|}{ Symptoms } \\
\hline Cough & $511(46.7)$ & $181(46.3)$ & 330 (46.9) \\
\hline Running nose & $470(43)$ & $124(31.7)$ & $346(49.2)$ \\
\hline Stuffy nose & $416(38.0)$ & $123(31.5)$ & $293(41.7)$ \\
\hline
\end{tabular}


medRxiv preprint doi: https://doi.org/10.1101/2022.02.16.22271075; this version posted February 21, 2022. The copyright holder for this preprint (which was not certified by peer review) is the author/funder, who has granted medRxiv a license to display the preprint in perpetuity.

It is made available under a CC-BY 4.0 International license .

\begin{tabular}{|l|c|c|c|} 
Sore throat & $531(48.5)$ & $161(41.2)$ & $370(52.6)$ \\
\hline Pain in swallowing & $239(21.8)$ & $53(13.6)$ & $186(26.5)$ \\
\hline Dyspnoea & $417(38.1)$ & $296(50.1)$ & $221(31.4)$ \\
\hline Headache & $565(51.6)$ & $250(63.9)$ & $315(44.8)$ \\
\hline Fever & $503(46.0)$ & $254(65.0)$ & $249(35.4)$ \\
\hline Fever with chills or sweating & $311(28.4)$ & $163(41.7)$ & $148(21.1)$ \\
\hline $\begin{array}{l}\text { Abdominal pain, nausea or } \\
\text { diarrhoea }\end{array}$ & $250(22.9)$ & $117(29.9)$ & $133(18.9)$ \\
\hline Impaired sense of smell or taste & $360(32.9)$ & $260(66.5)$ & $100(14.2)$ \\
\hline Myalgia & $459(42.0)$ & $227(58.1)$ & $232(33.0)$ \\
\hline Dizziness & $318(29.1)$ & $167(42.7)$ & $151(21.5)$ \\
\hline & & & $28(4.0)$ \\
\hline Fatigue, moderate and serious ${ }^{b}$ & $132(12.8)$ & $104(26.6)$ & \\
\hline
\end{tabular}

\footnotetext{
a One NOK= 0.096 Euro

${ }^{\mathrm{b}}$ Fatigue categories:1=no,

2=light, $3=$ =moderate, 4 =

serious

SD: Standard deviation
}

IQR: Interquartile range

Except for asthma (18\%), the prevalence of self-reported comorbidities was low for all participants. However, PCR+ participants reported more symptoms such as dyspnoea, headache, fever with chills or sweating, abdominal pain, nausea or diarrhoea, impaired sense of taste and smell, myalgia, and dizziness compared to the PCR- participants. In contrast, PCR- participants reported more nasal symptoms (runny/stuffy nose), sore throat, and pain upon swallowing compared to the PCR+ participants. Coughing was similar in both groups. Self-reported moderate or serious fatigue was more frequent among PCR+ than PCR- participants. Only 22 (6\%) of the PCR+ participants were hospitalised due to COVID-19. There were no self-reported reinfections during the study period.

The duration and changes in total antibody levels against the SARS-CoV-2 spike protein are shown in Table 2.

Table 2. The duration and changes in total antibody levels against the SARS-CoV-2 spike protein measured with Index value three to five months (T1) and 10 to 12 months (T2) after PCR test for PCR positive (PCR+) and PCR negative (PCR-) participants.

\begin{tabular}{|l|c|c|c|c|}
\hline $\begin{array}{c}\text { Time point to antibody } \\
\text { measurement }\end{array}$ & $\begin{array}{c}\text { Antibody } \\
\text { level } \\
\text { category in } \\
\text { Index } \\
\text { value }\end{array}$ & Total & PCR+ & PCR- \\
\hline T1 antibody & $0.00-0.79$ & $718(65.0)$ & $\mathrm{N}(\%)$ & $\mathrm{N}(\%)$ \\
\hline T1 antibody & $0.80-1.99$ & $27(2.5)$ & $26(6.4)$ & $1(0.1)$ \\
\hline T1 antibody & $2.00-9.99$ & $135(12.3)$ & $132(33.8)$ & $3(0.4)$ \\
\hline
\end{tabular}


medRxiv preprint doi: https://doi.org/10.1101/2022.02.16.22271075; this version posted February 21, 2022. The copyright holder for this preprint (which was not certified by peer review) is the author/funder, who has granted medRxiv a license to display the preprint in perpetuity.

It is made available under a CC-BY 4.0 International license.

\begin{tabular}{|c|c|c|c|c|}
\hline T1 antibody & $\geq 10$ & $213(19.5)$ & $208(53.2)$ & $5(0.7)$ \\
\hline T2 antibody & $0.00-0.79$ & & $8(3.8)$ & \\
\hline T2 antibody & $0.80-1.99$ & & $14(6.6)$ & \\
\hline T2 antibody & $2.00-9.99$ & & $63(29.7)$ & \\
\hline T2 antibody & $\geq 10$ & & $127(59.9)$ & \\
\hline $\begin{array}{l}\text { Decreased antibody level, } T 1 \text { to } \\
\text { T2 }\end{array}$ & & & $39(18.4)$ & \\
\hline $\begin{array}{l}\text { Unchanged antibody level, } \mathrm{T} 1 \text { to } \\
\mathrm{T} 2\end{array}$ & & & $35(16.5)$ & $2^{\mathrm{a}}$ \\
\hline $\begin{array}{l}\text { Increased antibody level, } T 1 \text { to } \\
\mathrm{T} 2\end{array}$ & & & $25(11.8)$ & $1^{a}$ \\
\hline Antibody level $\geq 10$ at $\mathrm{T} 1 \& \mathrm{~T} 2$ & & & $113(53.3)$ & \\
\hline
\end{tabular}

a Percent is not reported due to low number of participants with antibodies in this group.

Among the PCR+ participants, 366 (94\%) had total levels of antibodies $\geq 0.8$, and 208 (53\%) had total levels of antibodies at the upper limit of quantification three to five months after the positive PCR test. Twenty participants with uncertain antibody values were reanalysed; three of them showed no antibodies in the secondary test and were defined as false positives in the first test. Among the 212 participants with antibody measurements at both T1 and T2, 204 (96\%) had antibodies $\geq 0.8$, and 113 (53\%) had values above the upper limit of quantification of the total antibody at both measurements. The time between PCR and antibody measurements is shown in S2 Table.

The distribution of variables in PCR+ participants with decreased, unchanged, increased and antibody levels $\geq 10$ at time points T1 and T2 are shown in Table $\mathbf{3}$.

Table 3. The distribution of variables in PCR+ participants with detectable antibodies grouped as decreased, unchanged, increased, and antibody level $\geq 10$ at time point T1 and T2.

\begin{tabular}{|c|c|c|c|c|}
\hline Variable of interest ${ }^{a}$ & Decreased $\mathrm{N}=39$ & $\begin{array}{l}\text { Unchanged and } \\
\text { increased } \mathrm{N}=62\end{array}$ & $\begin{array}{l}\text { Antibody } \geq 10 \\
N=114\end{array}$ & $p$-value ${ }^{b}$ \\
\hline & $\mathbf{N}(\%)$ & $\mathrm{N}(\%)$ & $\mathbf{N}(\%)$ & \\
\hline Age in years, mean (SD) & $44.5(12.7)$ & $47.5(13.8)$ & $52.6(14.6)$ & 0.003 \\
\hline $\mathrm{N}$ (range) & $39(22-78)$ & $62(21-81)$ & $114(21-85)$ & \\
\hline $\mathrm{BMI} \geq 25.0 \mathrm{~kg} / \mathrm{m}^{2}$ & $26(68.4)$ & $24(40.0)$ & $65(59.1)$ & 0.011 \\
\hline Gender, males & $20(51.3)$ & $29(46.8)$ & $65(57.0)$ & 0.417 \\
\hline \multicolumn{5}{|l|}{ Income } \\
\hline$<500000$ NOK $^{\mathrm{c}}$ & $8(21.6)$ & $7(11.5)$ & $13(11.8)$ & \multirow[t]{3}{*}{0.605} \\
\hline $500000-1000000$ NOK & $11(29.7)$ & $22(36.1)$ & $49(44.5)$ & \\
\hline$\geq 1000000 \mathrm{NOK}$ & $18(48.6)$ & $32(52.5)$ & $48(43.6)$ & \\
\hline
\end{tabular}


medRxiv preprint doi: https://doi.org/10.1101/2022.02.16.22271075; this version posted February 21, 2022. The copyright holder for this preprint (which was not certified by peer review) is the author/funder, who has granted medRxiv a license to display the preprint in perpetuity.

It is made available under a CC-BY 4.0 International license.

\begin{tabular}{|c|c|c|c|c|}
\hline Education & & & & \\
\hline $\begin{array}{l}\text { Primary, secondary, and high } \\
\text { school }\end{array}$ & $17(44.7)$ & $23(37.7)$ & $51(45.1)$ & \multirow[t]{3}{*}{0.588} \\
\hline University less than 4 years & $14(36.8)$ & $24(39.3)$ & $41(36.3)$ & \\
\hline University more than 4 years & $7(18.4)$ & $14(23.0)$ & $21(18.6)$ & \\
\hline \multicolumn{5}{|l|}{ Smoking } \\
\hline Non-smoker & $28(80.0)$ & $36(64.3)$ & $57(53.8)$ & \multirow[t]{3}{*}{0.080} \\
\hline Past smoker & $5(14.3)$ & $15(26.8)$ & $39(36.8)$ & \\
\hline Occasional and daily smoker & $2(5.7)$ & $5(8.9)$ & $10(9.4)$ & \\
\hline \multicolumn{5}{|l|}{ Comorbidity } \\
\hline Asthma & $5(13.5)$ & $9(14.8)$ & $20(17.9)$ & 0.772 \\
\hline COPD & 0 & $1(1.6)$ & $4(3.7)$ & 0.583 \\
\hline Other chronic lung disease & $1(2.6)$ & $2(3.3)$ & $4(3.5)$ & 1.000 \\
\hline Cancer & $1(2.6)$ & $1(1.6)$ & $1(0.9)$ & 0.753 \\
\hline Heart disease & $2(5.3)$ & $3(4.9)$ & $7(6.2)$ & 1.000 \\
\hline Diabetes & 0 & $1(1.6)$ & $10(8.9)$ & 0.040 \\
\hline Hypertension & $2(5.3)$ & $2(3.3)$ & $16(14.2)$ & 0.048 \\
\hline Musculoskeletal disease & $2(5.3)$ & $2(3.3)$ & $4(3.5)$ & 0.790 \\
\hline Any other disease & $7(18.4)$ & $6(9.8)$ & $7(18.4)$ & 0.471 \\
\hline Comorbidity sum, mean (SD) & $0.5(0.7)$ & $0.4(0.7)$ & $0.7(0.9)$ & 0.100 \\
\hline Pollen allergy & $6(16.2)$ & $15(24.6)$ & $30(26.8)$ & 0.504 \\
\hline \multicolumn{5}{|l|}{$\begin{array}{l}\text { Symptoms by the time of } \\
\text { diagnosis of covid-19 }\end{array}$} \\
\hline Cough & $15(42.9)$ & $26(47.3)$ & $62(61.4)$ & 0.083 \\
\hline Running nose & $13(37.1)$ & $17(30.4)$ & $29(28.7)$ & 0.646 \\
\hline Stuffy nose & $15(42.9)$ & $18(32.1)$ & $30(28.8)$ & 0.309 \\
\hline Sore throat & $14(41.2)$ & $22(39.3)$ & $48(47.1)$ & 0.607 \\
\hline Pain upon swallowing & $4(11.4)$ & $7(12.5)$ & $15(14.6)$ & 0.921 \\
\hline Dyspnoea & $21(60.0)$ & $30(53.6)$ & $66(64.7)$ & 0.390 \\
\hline Headache & $28(82.4)$ & $43(76.8)$ & $70(68.0)$ & 0.197 \\
\hline Fever & $24(68.6)$ & $42(75.0)$ & $82(79.6)$ & 0.400 \\
\hline Fever with chills or sweating & $10(25.6)$ & $24(38.7)$ & $58(50.9)$ & 0.017 \\
\hline $\begin{array}{l}\text { Abdominal pain, nausea or } \\
\text { diarrhoea }\end{array}$ & $14(40.0)$ & $13(23.6)$ & $34(33.7)$ & 0.231 \\
\hline Impaired sense of smell or taste & $29(82.9)$ & $41(73.2)$ & $80(77.7)$ & 0.561 \\
\hline Myalgia & $21(60.0)$ & $29(52.7)$ & $73(70.9)$ & 0.068 \\
\hline Dizziness & $14(40.0)$ & $25(45.5)$ & $56(54.9)$ & 0.245 \\
\hline Number of symptoms, mean (SD) & $6.3(2.7)$ & $6.0(2.2)$ & $6.8(2.5)$ & 0.177 \\
\hline Fatigue $^{\mathrm{e}}$, moderate and serious & $7(20.0)$ & $10(17.0)$ & $42(38.5)$ & 0.006 \\
\hline
\end{tabular}

a Table 3 includes 212 PCR+ participants and three PCR- participants with detectable antibodies.

226 b P-value for comparison between decreased and the group (unchanged, increased, and antibody $\geq 10$ ).

227 c NOK= Norwegian kroner (One NOK=0.096 Euro)

$228 \mathrm{~d}$ COPD= Chronic obstructive pulmonary disease

229 e Fatigue categories:1=no, 2=light, 3=moderate, 4 = serious. 
medRxiv preprint doi: https://doi.org/10.1101/2022.02.16.22271075; this version posted February 21, 2022. The copyright holder for this preprint (which was not certified by peer review) is the author/funder, who has granted medRxiv a license to display the preprint in perpetuity.

It is made available under a CC-BY 4.0 International license .

231 Univariate and multivariate regression analyses were performed to assess the possible predictors for

232 antibody levels after 10-12 months, and to compare the group with decreased antibody levels with

233 the other groups (increased, unchanged, and antibody $\geq 10$ ), as shown in Table 4.

234

235 Table 4. Possible predictors for decreased antibodies after 10 to 12 months compared with

236 increased, unchanged and antibody $\geq 10$ using logistic regression.

\begin{tabular}{|c|c|c|c|c|c|c|c|c|c|}
\hline & & \multicolumn{4}{|c|}{$\begin{array}{l}\text { Univariate analysis } \\
\text { adjusted for age and sex }\end{array}$} & \multicolumn{4}{|c|}{$\begin{array}{l}\text { Multivariate analysis fully } \\
\text { adjusted }\end{array}$} \\
\hline & & OR & $2.5 \%$ & $97.5 \%$ & $\begin{array}{l}\mathrm{p}- \\
\text { value }\end{array}$ & OR & $2.5 \%$ & $97.5 \%$ & $\begin{array}{l}\text { p- } \\
\text { value }\end{array}$ \\
\hline Age (numeric) & & 0.97 & 0.94 & 0.99 & 0.01 & 0.97 & 0.93 & 1.00 & 0.030 \\
\hline Gender & Male & 0.92 & 0.46 & 1.85 & 0.81 & 0.77 & 0.32 & 1.85 & 0.563 \\
\hline BMI kg/m² & $\geq 25$ & 2.34 & 1.06 & 5.42 & 0.04 & 2.15 & 0.9 & 5.41 & 0.093 \\
\hline \multirow[t]{3}{*}{ Education } & $\begin{array}{l}\text { Below } \\
\text { University }\end{array}$ & / & & & & / & & & \\
\hline & $\begin{array}{l}\text { University }<4 \\
\text { years }\end{array}$ & 0.79 & 0.35 & 1.76 & 0.57 & 0.60 & 0.23 & 1.50 & 0.278 \\
\hline & $\begin{array}{l}\text { University } \geq 4 \\
\text { years }\end{array}$ & 0.83 & 0.30 & 2.15 & 0.71 & 0.50 & 0.14 & 1.62 & 0.265 \\
\hline \multirow[t]{3}{*}{ Income Norwegian kroner } & $<500000$ & / & & & & / & & & \\
\hline & $\begin{array}{l}500000- \\
1000000\end{array}$ & 0.47 & 0.16 & 1.41 & 0.17 & 0.61 & 0.19 & 2.12 & 0.425 \\
\hline & $>1000000$ & 0.62 & 0.23 & 1.77 & 0.35 & 0.82 & 0.25 & 2.87 & 0.743 \\
\hline \multirow[t]{3}{*}{ Smoking } & Non-smoker & / & & & & / & & & \\
\hline & Past smoker & 0.37 & 0.12 & 0.96 & 0.06 & 0.34 & 0.11 & 0.93 & 0.049 \\
\hline & $\begin{array}{l}\text { Daily and } \\
\text { occasional } \\
\text { smoker }\end{array}$ & 0.37 & 0.06 & 1.46 & 0.21 & 0.37 & 0.05 & 1.62 & 0.240 \\
\hline \multicolumn{10}{|l|}{ Symptoms } \\
\hline Symptoms score (numeric) & / & 1.0 & 0.85 & 1.08 & 0.48 & 0.97 & 0.84 & 1.11 & 0.612 \\
\hline \multirow[t]{2}{*}{ Dyspnoea } & No & / & & & & / & & & \\
\hline & Yes & 1.02 & 0.50 & 2.08 & 0.97 & \multicolumn{2}{|c|}{ not included } & & \\
\hline \multirow[t]{2}{*}{ Fever with chills/sweating } & No & / & & & & / & & & \\
\hline & Yes & 0.33 & 0.13 & 0.75 & 0.01 & \multicolumn{2}{|c|}{ not included } & & \\
\hline \multirow[t]{2}{*}{$\begin{array}{l}\text { Abdominal pain/diarrhoea/ } \\
\text { nausea }\end{array}$} & No & / & & & & / & & & \\
\hline & Yes & 1.69 & 0.78 & 3.59 & 0.18 & \multicolumn{2}{|c|}{ not included } & & \\
\hline \multirow[t]{2}{*}{ Loss of smell and taste } & No & / & & & & / & & & \\
\hline & Yes & 1.17 & 0.53 & 2.74 & 0.71 & \multicolumn{2}{|c|}{ not included } & & \\
\hline
\end{tabular}


medRxiv preprint doi: https://doi.org/10.1101/2022.02.16.22271075; this version posted February 21,2022 . The copyright holder for this preprint (which was not certified by peer review) is the author/funder, who has granted medRxiv a license to display the preprint in perpetuity.

It is made available under a CC-BY 4.0 International license.

\begin{tabular}{|l|l|l|l|l|l|l|l|l|l|l|}
\hline Comorbidity score & $/$ & 1.02 & 0.61 & 1.62 & 0.93 & 1.08 & 0.61 & 1.84 & 0.774 \\
\hline
\end{tabular}

\section{Discussion}

239 Total antibodies against the SARS-CoV-2 spike protein were detectable in $96 \%$ of the participants up

240 to 12 months after a positive PCR test. BMI $\geq 25 \mathrm{~kg} / \mathrm{m}^{2}$ was positively associated with decreased

241 antibody level (OR 2.34, 95\% Cl 1.06 to 5.42). Participants with higher age and self-reported initial

242 fever with chills or sweating were less likely to have decreased antibody levels (age: OR 0.97, $95 \% \mathrm{Cl}$

2430.94 to 0.99 ; fever: OR $0.33,95 \% \mathrm{Cl} 0.13$ to 0.75 ). There was no association between antibody

244 persistence and gender. Past smoking history was negatively associated with decreased antibody

245 levels (OR $0.37,95 \% \mathrm{Cl} 0.12$ to 0.96 ) in our study, but this finding should be interpreted with caution

246 because there were few smokers.

247

Among the PCR negative participants, nine had total antibodies $\geq 0.8$ at $\mathrm{T} 1$, and after initial symptoms, they did not report reinfection between the time of the PCR test and the antibody measurement. The most likely explanation is that they had COVID-19 and a false-negative PCR test, a test taken incorrectly or a low virus level at the time of the test.

We did not detect any self-reported reinfections during the study period. A recent large prospective multicentre cohort study from all the regions in England showed an $84 \%$ lower risk of reinfection after seven months of follow-up post SARS-CoV-2 infection among healthcare workers (HCWs) with positive antibodies tested with a range of assays [25]. The correlation between antibody levels and protective immunity remains unclear.

The results for antibody persistence after 10 to 12 months in our study were in accordance with those of several studies with a shorter follow-up time [9, 19, 21]. A seroprevalence study from Iceland reported that pan-IgG antibodies did not decline within four months after the diagnosis of SARS- CoV-2 infection in (91\% of the included subjects [26]. Furthermore, a study from the USA initially assessing 188 SARS-CoV-2 PCR-positive subjects showed durable spike IgG titres at six to eight months after symptom onset for 36 out of 40 individuals at follow-up [19]. Recently, a peerreviewed study by Turner et al. showed that in a follow-up of 42 COVID-19 convalescent patients, spike IgG antibodies were detectable at least 11 months after infection [9]. A recent cross-sectional study from USA showed antibodies at median 8.7 months after COVID-19 diagnosis [27].

Other studies that used different assays have shown contradictory results for antibody persistence with rapidly declining antibodies [15, 22]. There is a large heterogeneity in the test performance of different immunoassays [28]. Some studies have investigated nucleocapsid antibodies, which have been shown to decline faster than spike antibodies [29, 30]. A study of 97 participants in Korea showed declining nucleocapsid IgG antibody levels with reduction rates of $46 \%$ from six weeks to six months after diagnosis [29].

Lower persistence of $\lg G$ antibodies has been reported in asymptomatic compared to symptomatic COVID-19 patients two to three months after the PCR-confirmed SARS-CoV-2 infection in a study of 37 participants from China [15]. Accordingly, a study from Italy showed a declining antibody response with three different serological assays in 20 individuals with mild symptoms two months after the initial symptom onset [28]. 
medRxiv preprint doi: https://doi.org/10.1101/2022.02.16.22271075; this version posted February 21, 2022. The copyright holder for this preprint (which was not certified by peer review) is the author/funder, who has granted medRxiv a license to display the preprint in perpetuity.

It is made available under a CC-BY 4.0 International license .

spike protein at least four months post infection [30]. Antibodies were lower among HCWs than among 59 hospitalized COVID-19 patients. Most HCWs had mild symptoms prior to inclusion in the study.

Previous studies reporting factors associated with longevity of antibodies show a decline in antibodies or seronegativity among asymptomatic patients or patients with mild symptoms. Van Elslande et al. showed in their study that SARS-CoV-2 anti-nucleocapsid antibody levels were significantly lower in those with asymptomatic and mild SARS-CoV-2 infection than in those with severe disease, and that $61 \%$ of them became seronegative within 6 months post-PCR [32]. Hence, our findings of up to 12 month persistence in $96 \%$ of mainly non-hospitalised persons with mild symptoms are interesting. However the difference may be explained by the use of antibody against spike protein instead of nucleocapsid.

Our study agrees with other studies concerning the association between age and antibody persistence. In a 180 days follow-up study of 164 infected patients, Chia et al. found that antibody persistence was associated with disease severity, older age, and more comorbidities compared with those who had rapidly declining antibodies, although a greater proportion (11 of 19) of asymptomatic individuals were in the seronegative group [33].

$\mathrm{BMI} \geq 25 \mathrm{~kg} / \mathrm{m}^{2}$ was strongly associated with decreased antibody level in our study. This was not in agreement with a recent Norwegian study that showed the severity of initial illness, older age, and higher BMI were independently associated with increased antibody levels two months after infection [34]. A large prospective cohort study from the United States showed homogenous immune activity across BMI categories [35]. A large retrospective study from Israel showed that the peak level of neutralising antibodies was associated with obesity, with the highest level in patients who were severely obese [36]. The study did not include any follow-up antibodies. A study from Turkey showed no effect of BMI on antibody titres, but the sample size was small and the follow-up period was only 60 days [37]. Nevertheless, obesity was a risk factor for COVID-19 infection severity in many studies as shown in a meta-analysis of 42 studies [38]. It is possible that the diversity of the results of the association between BMI and antibody persistence after COVID-19 infection is dependent on disease severity.

There was no association between gender, income, education, and antibody persistence in our study. Socioeconomic differences in Norway are relatively small, and most of the included participants were from the middle class and above, as reflected in the high levels of education and income among the participants.

Our study has several strengths and limitations. A strength of our study is the relatively large and unselected study cohort recruited during the first and second pandemic waves in Norway. The time for the antibody test was related to the PCR test, and not the onset of symptoms. Another strength is the longitudinal design with a relatively long follow-up time. Validated serology assays were used, and the participants answered the questionnaire on the same day as the serum sampling.

A limitation of our study is that changes in antibody levels above the assay's upper limit value 10 Index could not be determined, but it is probably in the group with low antibody levels that significant changes will appear. Direct comparison of the current study's results with those of other studies is difficult because assays targeting different antigens are used in the available studies [10]. Further, differences in study populations, severity of illness, and frequency of antibody sampling make comparisons across studies challenging [31]. In our study, the same assay was used for all participants and as a quality control, all PCR- participants with detectable antibodies and all PCR+ participants with low levels of antibodies were retested with a second assay. Using two different 
medRxiv preprint doi: https://doi.org/10.1101/2022.02.16.22271075; this version posted February 21, 2022. The copyright holder for this preprint (which was not certified by peer review) is the author/funder, who has granted medRxiv a license to display the preprint in perpetuity.

It is made available under a CC-BY 4.0 International license .

assays was considered useful in low seroprevalence countries like Norway because of the possibility of false-positive tests [14].

The use of a self-reported questionnaire may be considered a limitation of the study because of recall bias. Further, the participants might not understand the questions as intended, and the response rates differed for the questions used. However, all questions included in the questionnaire were chosen from validated or frequently used questionnaires [21-24, 39].

Measurements of cellular immunity and neutralising antibodies were not feasible in this study, but it is important to consider when evaluating the immune status post COVID-19 [19]. T-cell responses in SARS-CoV-2 patients have been detected in recovered patients without an antibody response [40]. Early T-cell response may have an important role in protection against reinfections and recovering from SARS-COV-2 infection [41]. T-cell immunity is robust, and its memory might be longer-lasting [42].

\section{Conclusion}

In this Norwegian study of mainly non-hospitalized SARS CoV-2 PCR+ participants, $96 \%$ had high antibody levels and no reported reinfections were detected one year after the PCR tests. BMI $\geq 25$ $\mathrm{kg} / \mathrm{m}^{2}$ was positively associated with decreased antibody levels (OR $2.34,95 \% \mathrm{Cl} 1.06$ to 5.42). Participants with higher age and self-reported initial fever with chills or sweating were less likely to have decreased antibody levels (age: OR $0.97,95 \% \mathrm{Cl} 0.94$ to 0.99 ; fever: OR $0.33,95 \% \mathrm{Cl}$ 0.13 to 0.75 ). We did not detect an association between antibody persistence and gender. Our results indicate that the level of antibodies following mild COVID-19 persists for at least 10 to 12 months.

\section{Acknowledgements}

We thank Sølvi Noraas (Department of Clinical Microbiology, Kristiansand, Norway) for organising of the serological analysis in Agder. The authors are deeply grateful to Trude Belseth Sanden, Astrid Bjørkeid, June Bakstevold, Gølin Finkenhagen Gundersen, Emile van Gelderen, Elin Skjørvold Christensen, Louise Myrland, Signe Seljåsen, Mona Brekke, Siv Stigen, Anne Cecilie Tveiten, Oda Eikeland Myrnes and Siri Cathrine Rølland for their essential assistance for data collection and analysis. The authors would like to express their gratitude to all the participants in this study and to the patient representatives.

\section{References}

1. WHO. Weekly epidemiological Update and Weekly Operational Update. WHO; 2021. Available from: https://www.who.int/publications $/ \mathrm{m} /$ item/weekly-epidemiologicalupdate-on-covid-19---11-january-2022

2. FHI. Seroprevalence-of-sars-cov-2-in-the-norwegian-population. Available from: https://www.fhi.no/en/publ/2021/seroprevalence-of-sars-cov-2-in-the-norwegian-populationmeasured-in-residu/

3. Post N, Eddy D, Huntley C, van Schalkwyk MCl, Shrotri M, Leeman D, et al. Antibody response to SARS-CoV-2 infection in humans: A systematic review. PLOS ONE. 2020; 15: e0244126. doi: 10.1371/journal.pone.0244126. 
medRxiv preprint doi: https://doi.org/10.1101/2022.02.16.22271075; this version posted February 21, 2022. The copyright holder for this preprint (which was not certified by peer review) is the author/funder, who has granted medRxiv a license to display the preprint in perpetuity.

It is made available under a CC-BY 4.0 International license .

4. Khoshkam Z, Aftabi Y, Stenvinkel P, Paige Lawrence B, Rezaei MH, Ichihara G, et al. Recovery scenario and immunity in COVID-19 disease: A new strategy to predict the potential of reinfection. $J$ Adv Res. 2021;31: 49-60. doi: 10.1016/j.jare.2020.12.013.

5. Føns S, Krogfelt KA. How can we interpret SARS-CoV-2 antibody test results? Pathog Dis. 2021;79. doi: 10.1093/femspd/ftaa069.

6. Arkhipova-Jenkins I, Helfand M, Armstrong C, Gean E, Anderson J, Paynter RA, et al. Antibody response After SARS-CoV-2 infection and implications for immunity: A rapid living review. Ann Intern Med. 2021; 174: 811-821. doi: 10.7326/M20-7547.

7. Crawford KHD, Dingens AS, Eguia R, Wolf CR, Wilcox N, Logue JK, et al. Dynamics of neutralizing antibody titers in the months after SARS-CoV-2 infection. J Infect Dis. 2020. doi: $10.1093 /$ infdis/jiaa618

8. Iyer AS, Jones FK, Nodoushani A, Kelly M, Becker M, Slater D, et al. Persistence and decay of human antibody responses to the receptor binding domain of SARS-CoV-2 spike protein in COVID-19 patients. Sci Immunol. 2020; 5. doi: 10.1126/sciimmunol.abe0367.

9. Turner JS, Kim W, Kalaidina E, Goss CW, Rauseo AM, Schmitz AJ, et al. SARS-CoV-2 infection induces long-lived bone marrow plasma cells in humans. Nature. 2021; 595: 421-425. doi: 10.1038/s41586-021-03647-4.

10. National SARS-CoV-2 Serology Assay Evaluation Group. Performance characteristics of five immunoassays for SARS-CoV-2: a head-to-head benchmark comparison. Lancet Infect Dis. 2020; 20: 1390-1400. doi: 10.1016/S1473-3099(20)30634-4.

11. Long QX, Liu BZ, Deng HJ, Wu GC, Deng K, Chen YK, et al. Antibody responses to SARS-CoV-2 in patients with COVID-19. Nat Med. 2020; 26: 845-848. doi: 10.1038/s41591-020-0897-1.

12. Lumley SF, Wei J, O'Donnell D, Stoesser NE, Matthews PC, Howarth A, et al. The duration, dynamics and determinants of SARS-CoV-2 antibody responses in individual healthcare workers. Clin Infect Dis. 2021; 73: e699-e709. doi: 10.1093/cid/ciab004.

13. Clapham H, Hay J, Routledge I, Takahashi S, Choisy M, Cummings D, et al. Seroepidemiologic study designs for determining SARS-COV-2 transmission and immunity. Emerg Infect Dis. 2020; 26: 1978-1986. doi: 10.3201/eid2609.201840.

14. Ripperger TJ, Uhrlaub JL, Watanabe M, Wong R, Castaneda Y, Pizzato HA, et al. Orthogonal SARS-CoV-2 serological assays enable surveillance of low-prevalence communities and reveal durable humoral immunity. Immunity. 2020; 53: 925-933.e4. doi: 10.1016/i.immuni.2020.10.004.

15. Long QX, Tang XJ, Shi QL, Li Q, Deng HJ, Yuan J, et al. Clinical and immunological assessment of asymptomatic SARS-CoV-2 infections. Nat Med. 2020;26: 1200-1204. doi: 10.1038/s41591-0200965-6.

16. Ibarrondo FJ, Fulcher JA, Goodman-Meza D, Elliott J, Hofmann C, Hausner MA, et al. Rapid decay of anti-SARS-CoV-2 antibodies in persons with mild Covid-19. N Engl J Med. 2020;383: 10851087. doi: $10.1056 /$ NEJMc2025179.

17. Van Elslande J, Oyaert M, Ailliet S, Van Ranst M, Lorent N, Vande Weygaerde $Y$, et al. Longitudinal follow-up of IgG anti-nucleocapsid antibodies in SARS-CoV-2 infected patients up to eight months after infection. J Clin Virol. 2021; 136: 104765. doi: 10.1016/i.jcv.2021.104765. 18. L'Huillier AG, Meyer B, Andrey DO, Arm-Vernez I, Baggio S, Didierlaurent A, et al. Antibody persistence in the first 6 months following SARS-CoV-2 infection among hospital workers: a prospective longitudinal study. Clin Microbiol Infect. 2021; 27: 784.e1-784.e8. doi:

10.1016/j.cmi.2021.01.005.

19. Dan JM, Mateus J, Kato Y, Hastie KM, Yu ED, Faliti CE, et al. Immunological memory to SARSCoV-2 assessed for up to 8 months after infection. Science. 2021; 371. doi: 10.1126/science.abf4063. 20. Wajnberg A, Amanat F, Firpo A, Altman DR, Bailey MJ, Mansour M, et al. Robust neutralizing antibodies to SARS-CoV-2 infection persist for months. Science. 2020; 370: 1227-1230. doi: 10.1126/science.abd7728.

21. Tunheim G, Laake I, Robertson AH, Waalen K, Hungnes O, Naess LM, et al. Antibody levels in a cohort of pregnant women after the 2009 influenza $A(H 1 N 1)$ pandemic: waning and association 
medRxiv preprint doi: https://doi.org/10.1101/2022.02.16.22271075; this version posted February 21, 2022. The copyright holder for this preprint (which was not certified by peer review) is the author/funder, who has granted medRxiv a license to display the preprint in perpetuity.

It is made available under a CC-BY 4.0 International license .

with self-reported severity and duration of illness. Influ Other Respir Viruses. 2019;13: 191-200. doi: 10.1111/irv.12623.

22. Abrahamsen R, Fell AK, Svendsen MV, Andersson E, Torén K, Henneberger PK, et al. Association of respiratory symptoms and asthma with occupational exposures: findings from a population-based cross-sectional survey in Telemark, Norway. BMJ Open. 2017; 7: e014018. doi: 10.1136/bmjopen-2016-014018.

23. Caspersen IH, Magnus P, Trogstad L. Excess risk and clusters of symptoms after COVID-19 in a large Norwegian cohort. medRxiv: 2021:2021.10.15.21265038. doi: 10.1101/2021.10.15.21265038. 24. Trogstad L, Robertson AH, Mjaaland S, Magnus P. Association between ChAdOx1 nCoV-19 vaccination and bleeding episodes: large population-based cohort study. Vaccine. 2021; 39: 58545857. doi: 10.1016/j.vaccine.2021.08.055.

25. Hall VJ, Foulkes S, Charlett A, Atti A, Monk EJM, Simmons R, et al. SARS-CoV-2 infection rates of antibody-positive compared with antibody-negative health-care workers in England: a large, multicentre, prospective cohort study (SIREN). Lancet. 2021; 397: 1459-1469. doi: 10.1016/S01406736(21)00675-9.

26. Gudbjartsson DF, Norddahl GL, Melsted P, Gunnarsdottir K, Holm H, Eythorsson E, et al. Humoral immune response to SARS-CoV-2 in Iceland. N Engl J Med. 2020; 383: 1724-1734. doi: 10.1056/NEJMoa2026116.

27. Alejo JL, Mitchell J, Chang A, Chiang TPY, Massie AB, Segev DL, et al. Prevalence and Durability of SARS-CoV-2 Antibodies Among Unvaccinated US Adults by History of COVID-19. Jama. 2022 Feb 3. doi: 10.1001/jama.2022.1393.

28. Anichini G, Gandolfo C, Terrosi C, Fabrizi S, Miceli GB, Gori Savellini G, et al. Antibody response to SARS-CoV-2 in infected patients with different clinical outcome. J Med Virol. 2021;93(4):2548-2552. doi: 10.1002/jmv.26789

29. Noh JY, Kwak JE, Yang JS, Hwang SY, Yoon JG, Seong H, et al. Longitudinal assessment of antiSARS-CoV-2 immune responses for six months based on the clinical severity of COVID-19. J Infect Dis. 2021;223:754-763. doi: 10.1093/infdis/iiab124

30. Havervall S, Jernbom Falk A, Klingström J, Ng H, Greilert-Norin, N.Gabrielsson et al. SARS-CoV-2 induces a durable and antigen specific humoral immunity after asymptomatic to mild COVID-19 infection. PLOS ONE. 2022; 17: e0262169. doi: 10.1371/journal.pone.0262169.

31. Manisty C, Treibel TA, Jensen M, Semper A, Joy G, Gupta RK, et al. Time series analysis and mechanistic modelling of heterogeneity and sero-reversion in antibody responses to mild SARS-CoV2 infection. EBioMedicine. 2021;65:103259. doi: 10.1016/j.ebiom.2021.103259.

32. Van Elslande J, Oyaert M, Ailliet S, Van Ranst M, Lorent N, Vande Weygaerde $\mathrm{Y}$, et al. Longitudinal follow-up of IgG anti-nucleocapsid antibodies in SARS-CoV-2 infected patients up to eight months after infection. J Clin Virol. 2021;136:104765. doi: 10.1016/j.jcv.2021.104765. 33. Chia WN, Zhu F, Ong SWX, Young BE, Fong SW, Le Bert N, et al. Dynamics of SARS-CoV-2 neutralising antibody responses and duration of immunity: a longitudinal study. Lancet Microbe. 2021; 2: e240-e249. doi: 10.1016/S2666-5247(21)00025-2.

34. Blomberg B, Mohn KG, Brokstad KA, Zhou F, Linchausen DW, Hansen BA, et al. Long COVID in a prospective cohort of home-isolated patients. Nature medicine. 2021; 27: 1607-1613. doi: 10.1038/s41591-021-01433-3.

35. Nilles EJ, Siddiqui SM, Fischinger S, Bartsch YC, de St Aubin M, Zhou G, et al. Epidemiological and Immunological Features of Obesity and SARS-CoV-2. Viruses. 2021;13. doi: 10.3390/v13112235. 36. Soffer S, Glicksberg BS, Zimlichman E, Efros O, Levin MA, Freeman R, et al. The association between obesity and peak antibody titer response in COVID-19 infection. Obesity (Silver Spring). 2021;29(9):1547-1553. doi: 10.1002/oby.23208.

37. Ozgocer T, Dagli ŞN, Ceylan MR, Disli F, Ucar C, Yildiz S, et al. Analysis of long-term antibody response in COVID-19 patients by symptoms grade, gender, age, BMI, and medication. J Med Virol. 2021. doi: $10.1002 / j m v .27452$. 
medRxiv preprint doi: https://doi.org/10.1101/2022.02.16.22271075; this version posted February 21, 2022. The copyright holder for this preprint (which was not certified by peer review) is the author/funder, who has granted medRxiv a license to display the preprint in perpetuity.

It is made available under a CC-BY 4.0 International license.

38. Dessie ZG, Zewotir T. Mortality-related risk factors of COVID-19: a systematic review and meta-analysis of 42 studies and 423,117 patients. BMC Infect Dis. 2021;21:855. doi: 10.1186/s12879021-06536-3.

39. Torén K, Brisman J, Järvholm B. Asthma and asthma-like symptoms in adults assessed by questionnaires. A literature review. Chest. 1993;104(2):600-8.

40. Ong DSY, Fragkou PC, Schweitzer VA, Chemaly RF, Moschopoulos CD, Skevaki Cea. How to interpret and use COVID-19 serology and immunology tests. Clin Microbiol Infect. 2021;27:981-6. doi: 10.1016/j.cmi.2021.05.001.

41. Goletti D, Petrone L, Manissero D, Bertoletti A, Rao S, Ndunda N, et al. The potential clinical utility of measuring severe acute respiratory syndrome coronavirus 2 -specific T-cell responses. Clin Microbiol Infect. 2021;27:1784-9. doi: 10.1016/j.cmi.2021.07.005.

42. Sekine T, Perez-Potti A, Rivera-Ballesteros O, Strålin K, Gorin JB, Olsson A, et al. Robust T Cell Immunity in Convalescent Individuals with Asymptomatic or Mild COVID-19. Cell. 2020;183(1):15868.e14. doi: 10.1016/j.cell.2020.08.017

\section{Supporting information}

S1 Table. Questions from the questionnaire concerning demographic data, hospitalisation, comorbidities, symptoms and fatigue.

S2 Table. The median time between positive PCR and antibody measurements. The median time between positive PCR and T1 antibody measurement was 127 days (91-153) and between positive PCR and T2 antibody 310 days (291-329). Among the PCR negative participants, the median time between PCR test and T1 total antibody was 200 days (114-217).

Authors' contributions

Conceptualization: Anne Kristin Møller Fell, Hege Kersten, Randi Eikeland, Yngvar Tveten, Carina Thilesen, Marjut Sarjomaa, Neil Pearce, Jan Paul Vandenbroucke

Data Curation: Anne Kristin Møller Fell, Marjut Sarjomaa, Harald Reiso, Kristine Karlsrud Berg

Formal Analysis: Lien my Diep, Chi Zhang

Funding Acquisition: Anne Kristin Møller Fell, Marjut Sarjomaa

Investigation: Marjut Sarjomaa, Randi Eikeland, Kristine Karlsrud Berg, Harald Reiso, Yngvar Tveten, Carina Thilesen

Methodology: Anne Kristin Møller Fell, Neil Pearce, Jan Paul Vandenbroucke

Project Administration: Anne Kristin Møller Fell

Resources: Marjut Sarjomaa, Yngvar Tveten, Randi Eikeland, Carina Thilesen, Kristine Karlsrud Berg, Svein Arne Nordbø

Supervision: Anne Kristin Møller Fell, Hege Kersten, Yngvar Tveten

Validation: All authors 
medRxiv preprint doi: https://doi.org/10.1101/2022.02.16.22271075; this version posted February 21, 2022. The copyright holder for this preprint (which was not certified by peer review) is the author/funder, who has granted medRxiv a license to display the preprint in perpetuity.

It is made available under a CC-BY 4.0 International license.

509 Visualization: Anne Kristin Møller Fell, Marjut Sarjomaa, Randi Eikeland

510 Writing - Original Draft Preparation: Marjut Sarjomaa, Anne Kristin Møller Fell

511 Writing - Review \& Editing: All authors

512

513

514 


\section{Excluded $(\mathrm{N}=232)$ $<18$ years $(\mathrm{N}=55)$ Language barrier $(\mathrm{N}=3)$ \\ Deceased $(\mathrm{N}=14)$ No contact $(\mathrm{N}=150)$ Other $(\mathrm{N}=10)$

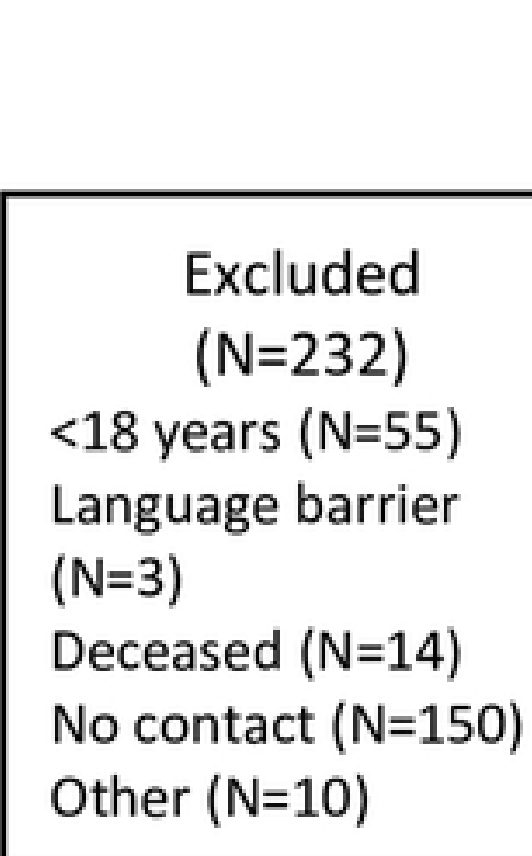

PCR+ eligible

$(\mathrm{N}=656)$

\section{Declined}

medRxiv prepriqt doi: https;//doi.org/10.1101/2022 02 16.22271075: th $/$ version posted February 21, 2022. The copyright holder for this preprint (whidh 20 bttertified by peer review) is the authorffunder, who has granted medRxiv a license to display the preprint in It is made available under a CC- $\$$ YY 4.0 International license.

\begin{tabular}{|c|}
\hline $\begin{array}{c}\text { Excluded } \\
\text { Inconclusive PCR } \\
(\mathrm{N}=3)\end{array}$ \\
\hline $\begin{array}{c}\text { Excluded } \\
\text { Vaccinated before T1 } \\
(\mathrm{N}=9)\end{array}$ \\
\hline
\end{tabular}

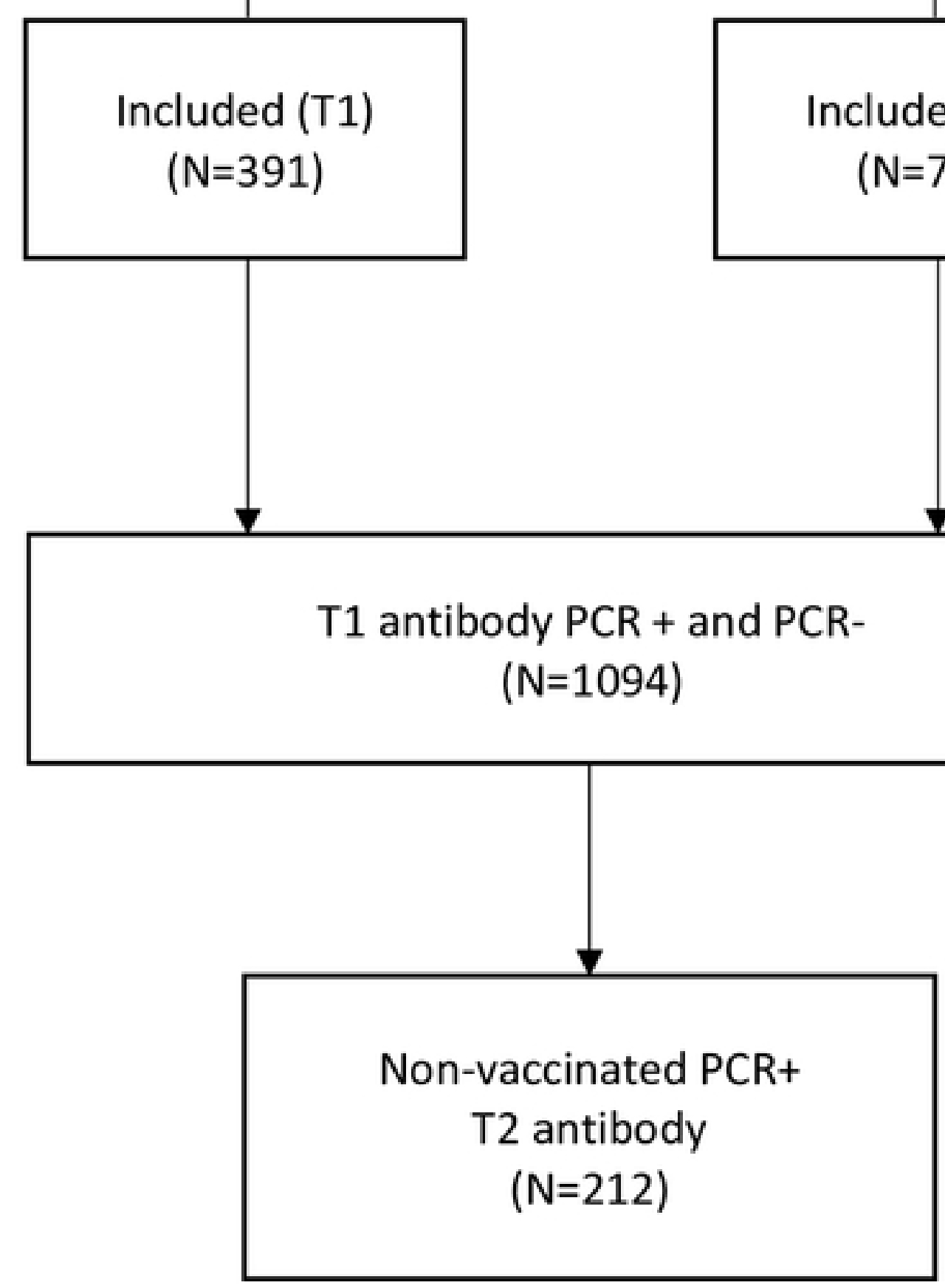

PCR- eligible

$(\mathrm{N}=923)$

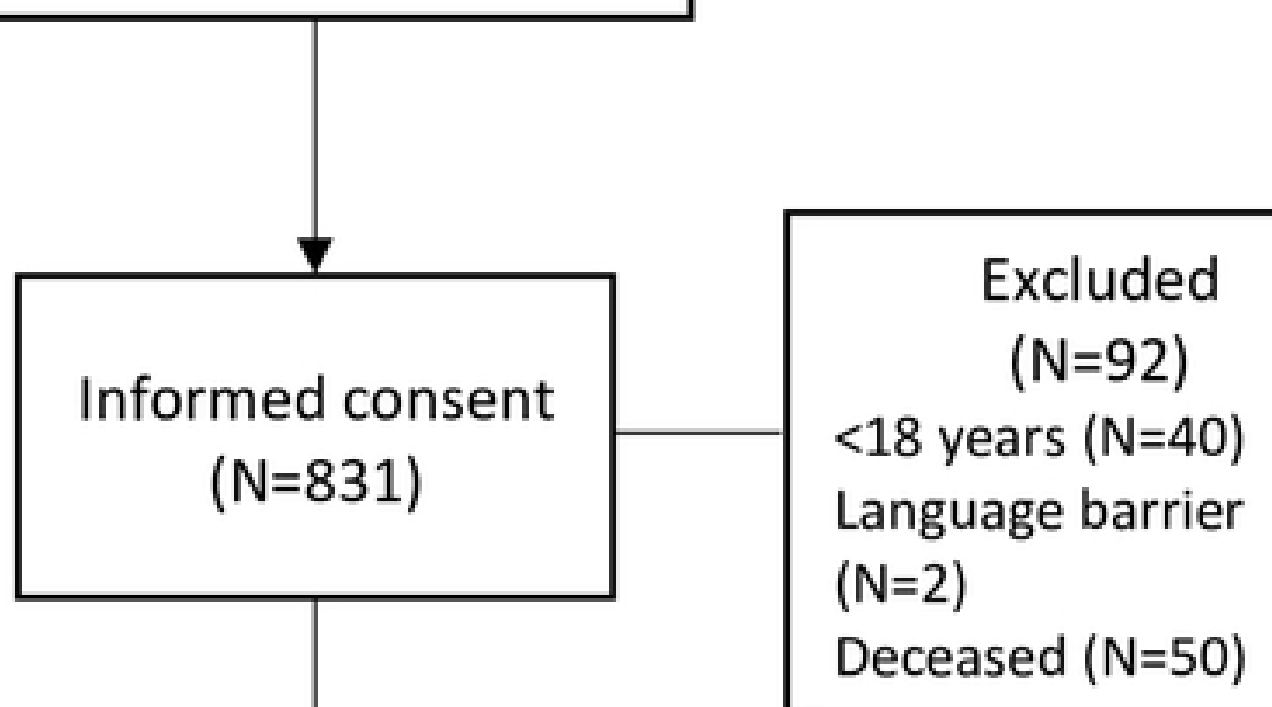

